que parecem acreditar que são livres apenas à medida que lhes é permitido entregaremse à licenciosidade e que renunciam a seus direitos se são obrigados a viver conforme os preceitos da lei divina. Acreditam, assim, que a civilidade e a religiosidade e, em geral, tudo que está referido a fimeza do ânimo, são fardos de que eles esperam livrarse depois da morte, para, então, receber o preço da sua servidão, ou seja, da civilidade e da religiosidade. E não é apenas por essa esperança, mas também, e sobretudo, pelo medo de serem punidos, depois da morte, por cruéis suplícios, que eles são levados a viver, tanto quanto o permitem sua fraqueza e seu ânimo impotente, conforme os preceitos da lei divina. Se os homens não tivessem essa esperança e esse medo, e acreditassem, em vez disso, que as mentes morrem juntamente com o corpo, e que não está destinada, aos infelizes esgotados pelo fardo da civilidade uma outra vida, além desta, eles voltariam a sua maneira de viver, preferindo entregar-se a licenciosidade e obedecer ao acaso e não a si mesmos".

5. "Todas as ações que seguem dos afetos referidos à Mente enquanto intelige eu refiro à Fortaleza, que distingo em Firmeza e Generosidade. Pois por Firmeza entendo o Desejo pelo qual cada um se esforça para conservar seu ser pelo só ditame da razão. Por Generosidade entendo o Desejo pelo qual cada um se esforça para favorecer os outros homens e uni-los a si por amizade pelo só ditame da razão."

6. Quanto ao tratamento do amor por parte de Descartes ver Boros 3.

7. Talvez não seja inapropriado lembrar, neste ponto, que Alexandre Matheron desenvolveu uma reconstrução evolucionista do conceito spinozista da gênese de um estado, precisamente ao longo destas linhas, baseado no Tratado Político de Spinoza, contra aqueles que sustentam que Spinoza seja um filósofo contratualista. Podemos encontrar esta análise em Matheron 9, p. 258-270.

8. Note que a expressão "bem-aventurança" (beatitudo) atesta o encadeamento da moralidade e da (reinterpretada) religião, que equivale a prover ambos de um caráter "secularizado".

9. "quando elevamos nosso espírito para considerá-lo tal qual ele é [o verdadeiro objeto do amor, que é a perfeição], encontramos a nós mesmos naturalmente tão inclinados para amá-lo, que tiramos a alegria mesmo de nossas aflições, ao pensar que sua vontade se realiza nisto que as recebemos."

10. De seu próprio movimento ou vontade (N.T.).

\section{HERMENÊUTICA E PLURALISMO SUBJETIVO: O FUNDAMENTO DA LIBERDADE NO PENSAMENTO DE \\ ESPINOSA}

\section{Victor-Manuel Pineda Santoyo*}

Resumo: Este trabalho tem como propósito central expor uma das aspirações mais caras à filosofia de Espinosa: a liberação da faculdade de julgar, tanto como perspectiva hermenêutica como em seu significado político. A partir deste conceito, pretendese reconstruir alguns tramos do programa do filósofo, sempre enfático a respeito da liberdade, tanto no âmbito ético como no político, e os diversos significados que esta tem em sua obra. Há uma liberdade concebida sub specie aeternitatis e uma liberdade sub specie durationis? A questão leva a estabelecer a relação que este filósofo tem com as coisas do mundo político, sempre movido a partir de paixões e interesses e, frequentemente, afastado de um sentido virtuoso da liberdade. Sem abandonar as aspirações de um sentido superior da liberdade, o autor sustenta que Espinosa se propõe examinar o problema da liberdade em um contexto no qual há mais prejuízos que idéias adequadas, mais temores que esperanças, mais superstição que sabedoria. Palavras-chave: liberdade, hermenêutica bíblica, faculdade de julgar.

\section{A fonte das liberdades subjetivas}

Nas páginas mais notáveis do pensamento espinosano concorrem diversos graus e concepções da liberdade. Essas noções sempre foram vinculadas por Espinosa à diversidade de técnicas intelectuais que possui o entendimento para percepções das coisas: da mesma forma podiam ser referidas à constituição imaginária da subjetividade, isto é, ao erro e às ficções mais delirantes, como à potência que a alma possui para ser

* Professor de Filosofia na Univerdad Nicolaita - México.

Texto traduzido por Daniel Santos (Doutorando do Departamento de Filosofia da USP). 
fonte ativa de todas as suas ideias. Um nível da liberdade se assume como uma reivindicação racional desta, e, inclusive, é concebida no marco das aspirações mais veementes de seu pensamento, o da construção de uma liberdade surgida no marco da cidade constituída em função de valores superiores. ${ }^{1}$ Há, assim mesmo, outro plano da liberdade que não está vinculado com a racionalidade senão com a aspiração a exercê-la desde o reconhecimento da divergência dos "modos de pensamento" que possui uma comunidade: se trata de uma defesa da liberdade que assume que o princípio sobre o qual se deve edificar uma sociedade é a aceitação do dissenso nos afetos e que exige que a imunidade do juízo seja a garantia mais sagrada das liberdades. Os argumentos espinosanos a favor da liberdade são igualmente sagazes quando explicam uma condição na qual ela não coincide ainda com a virtude. Reclama os direitos à liberdade inclusive para defender a pobreza intelectual dos espíritos menos nobres: os dos supersticiosos. O terreno no qual se dão as disputas sobre a subjetividade se expressa nas diferentes narrações que existem sobre a ideia de Deus: a dos profetas e a dos filósofos, a que surge da teologia revelada e a do saber construído no recinto da razão. Espinosa estabeleceu esse legado a favor da liberdade a partir do suposto de que todas as representações, racionais ou imaginárias, são geradas a partir da relação dos homens com a ideia de Deus. As formas dessa relação assumem particularidades que ele estudou minuciosamente em toda a sua obra; com efeito, podemos encontrar uma consistente reflexão acerca de todos os gêneros de elaboração racional, imaginária, simbólica e, no contexto de seus tratados políticos, e nas conseqüências que esta tem em seu posicionamento social. Sua Ética pode ser explicada como dirigida à geração de uma ideia racional de Deus; ${ }^{2}$ toda essa obra concentra seus recursos mais persuasivos na concepção de uma filosofia teocêntrica, porém apartada dos artigos mais dogmáticos da revelação. Entre a liberdade que nos foi concedida pela natureza e a liberdade que se conquista através do poder reformador da ideia de Deus, existe um vasto mundo de ideias, de afetos, de paixões e de interpretações; essa multidão de ideias que se desdobram no seio da vida social requer que sejam reconhecidas em sua diversidade e, sobretudo, no reconhecimento dos limites naturais da autoridade para guiá-las neste ou naquele sentido.

A chave na qual Espinosa compreende a representação de Deus no plano político lhe impôs a necessidade de expor essa questão em um registro distinto daquele que oferece em sua Ética: pretende estudar os mecanismos imaginários que assume a ideia de Deus na trama que forma a cidade. É de suma importância sublinhar o fato de que Espinosa contrai duas posturas divergentes em razão dos propósitos de que pretende dar conta: a Ética é um livro que se desdobra sobre a construção de uma ideia adequada de Deus e põe a questão do conhecimento como um guia para assinalar o caminho da conversão intelectual dos homens guiados pela luz da razão. O Tratado teológico-político e o Tratado político assumiriam uma visão imposta pela necessidade de pensar a natureza das circunstâncias e os acontecimentos ocorridos no domínio da vida coletiva. A ideia de Deus gera, para este filósofo, convergências e divergências, articula e dissolve relações sociais, comporta argúcias a favor da guerra e serve à reconciliação, envolve a superstição e a lucidez. No entanto, a questão não é que todos os homens tendem a possuir uma ideia de Deus senão qual é o domínio a partir do qual se forja essa ideia. Entre o Deus da ágora e o Deus surgido dos mais agudos instrumentos da razão há uma diferença de grau e não uma de natureza: essa diferença é trazida pela origem de que derivam um e outro e os planos intelectuais aos quais correspondem: a imaginação e a razão. ${ }^{3}$ Um filósofo como Espinosa parte do suposto de que a razão possui um papel que tende a constituir laços humanos nascidos da virtude e, ao mesmo tempo, formula toda classe de críticas à imaginação que dissolve os laços da concórdia, da solidariedade e da generosidade. 
Não formulou seus votos filosóficos somente em função de que a razão contribua para os verdadeiros laços de amizades entre os homens; o faz a partir de uma convicção mais profunda: sua exigência de que a vida social não se reduza à mera congregação de homens e sim que avance essa aliança até a conquista da liberdade.

Haveria uma espécie de distinção espinosana pela qual se explique a Deus como uma espécie de idola fori e a irrupção de um Deus concebido a partir dos emaranhados conceituais mais sólidos da filosofia? ${ }^{4}$ Assumimos de entrada que a filosofia de Espinosa se expõe em dois planos: um que aspira a construir uma filosofia perene e sujeita às propensões eternas da razão; a outra perspectiva parece inclinada a interrogar sobre as coisas mais seculares que ocorrem ao homem comum e corrente: se propõe a formular uma alegação a favor da liberdade dos homens de razão e reivindica o direito de todos os indivíduos a professar suas próprias crenças em um marco de pluralismo subjetivo. A liberdade exercida no horizonte multitudinário da cidade, a da realização da plena natureza dos indivíduos, se desdobra originariamente a partir da interpretação autônoma destes sobre as Escrituras. A partir dessa neutralização de toda autoridade em matéria de interpretação, quer dizer, da coincidência entre poder e religião, Espinosa abre um dos capítulos mais decisivos na edificação da modernidade: o sentido da liberdade abre passagem a partir do reconhecimento da soberania do indivíduo sobre suas crenças e ideias. Os escritos políticos espinosanos estão consagrados a romper com o exercício mais dogmático e autoritário da interpretação dos textos sagrados; demandam que todo exercício hermenêutico repouse sobre uma liberdade que o indivíduo possui originariamente, a de julgar em função de sua própria constituição intelectual, à margem de algo que a cidade não pode nem deve arrogar-se: o direito natural ao discernimento autônomo.

\section{A falsa e a verdadeira religião}

Uma das impugnações mais persistentes que formula Espinosa se dirige contra a superstição. Não se limita a denunciar os estragos que provoca na ordem da vida social: se impõe a tarefa de compreender o modus operandi de todas as representações imaginárias que forma para si todo homem que ignora a verdadeira causa das coisas. A ignorância e a superstição se instalam ali onde não se pode atribuir uma explicação causal a um acontecimento ou a uma coisa. As motivações da Ética e os tratados que a precedem estão inspirados por um zelo intenso e infatigável: exibir as causas dos delírios da imaginação. Espinosa impõe a si a tarefa de compreender adequadamente como se formam as ideias mais ilusórias com a mesma minúcia com que exibe a estirpe das ideias adequadas. Quer combater a imaginação conhecendo-la em suas entranhas mais abismais. Um discurso reformador como o que ostenta Espinosa começa fazendo um reconhecimento do terreno sobre o qual pretende desenvolver a ação de reconversão intelectual da humanidade; assume, em certo sentido, que todo intento de reforma social é banal se não se articula com a necessidade de explicar as origens de um tipo de subjetividade submetida ao despotismo da ignorância.

Quais são as molas que impulsionam a superstição a seus mais enérgicos transes? O desejo é um dos elementos que estão implicados na geração da superstição. Espinosa atribui ao desejo um poder tal que, a partir dele, derivam-se uma pluralidade de acontecimentos que expressam todas as inclinações que jogam o homem em diversas direções. Uma explicação comum à Ética e ao Tratado teológico-político consiste em assinalar a duas paixões derivadas do desejo todos os motivos pelos quais o homem pode gerar as mais diversas formas de culto ao absurdo: o medo e a esperança: “... e daqui surgiram as superstições, cujos conflitos sofrem 
em toda parte os homens. Não creio, além disso, que valha a pena mostrar aqui que as flutuações de ânimo que nascem da esperança e do medo, já que da só definição destes afetos se segue que não se tem esperança sem medo nem medo sem esperança (como explicaremos mais amplamente em seu lugar); e porque, do mais, na medida em que esperamos ou tememos algo, o amamos ou odiamos" (Espinosa 2, III, P50, esc., p.159). De sua parte, as primeiras palavras do Tratado teológico-político partem com a mesma determinação a criticar as origens da superstição: "Se todos os homens pudessem conduzir todos os seus assuntos segundo um critério firme, ou se a fortuna lhes fosse sempre favorável, nunca seriam vítimas da superstição" (Espinosa 3, prefácio, p.61). Ora, essas formulações têm um vazio específico: a imagem puramente exterior de Deus que se traduz em uma fonte de concepções distorcidas sobre sua natureza. Os enclaves a partir dos quais se propõe estudar a imagem externa das religiões tradicionais são os cultos e as cerimônias instituídas pelos regimes teocráticos aos quais aludem as histórias bíblicas; porém, nesta reconstrução das circunstâncias histórico-hermenêuticas da Bíblia, não encontra um mero propósito erudito. As formas da idolatria e de superstição que estuda estão submetidas à exigência de expor todas aquelas práticas que criaram os prejuízos que limitam as liberdades subjetivas na nascente modernidade. ${ }^{5}$ A hermenêutica espinosana não apenas assume uma função crítica a partir da qual destrói o continuum entre poder e fé: se desenvolve a partir da necessidade de explicar a liberdade em suas origens mais impuras, contudo igualmente mais incontestáveis; interpretar é um direito do qual não se pode declinar a favor da autoridade. Isso vale tanto para o filósofo que propõe a si a livre indagação como para o ignorante que imagina a natureza das coisas.

O filósofo de Amsterdã está longe de pretender que as religiões desapareçam do mapa dos afetos humanos; em todo caso, sua tentativa está orientada a despojar as religiões da superstição, pois uma crítica ilustrada destas não consiste em suplantá-las, senão, inicialmente, depurá-las de toda aquela mitologia que justifica o terror e a servidão tão arraigados no mundo social. A distinção entre a falsa e a verdadeira religião é um dos meios formulados para esse propósito; ao longo de toda a sua obra está presente esse eixo, embora sob diversas formulações. A Ética ataca o tema da diferença entre uma imagem exterior e uma ideia adequada de Deus; parte de uma teoria do conhecimento que se propõe formular as normas que servem para reconhecer os gêneros de conhecimento que são adequados ou inadequados em relação à representação de Deus. De sua parte, os tratados políticos a constroem em função da ideia da falsa e da verdadeira religião; a necessidade explicativa que se encontra na formulação desta última distinção consiste no fato de que Espinosa não menospreza o valor da religião, com a condição de que se encontre associada à filosofia e não às superstições. A superação da superstição é obra da filosofia, porém esse deslocamento do intelecto até uma verdadeira religião não consiste no abandono dos valores, como a generosidade e a animosidade, sim em substituir pela virtude interna as afecções funestas como o temor e a esperança. A questão conduz, assim mesmo, a estabelecer qual é a religião da liberdade e qual é a religião que está a serviço da servidão e dos prejuízos. Enquanto o conteúdo da profecia tende a refugiar-se no mistério, na revelação e nos signos, Espinosa coloca a razão no lugar mais visível: suas atividades se desenvolvem à vista de todos, longe dos véus dos poderes carismáticos; não a concebe como uma visão privilegiada, sim como uma esfera a que todo homem pode aceder. $\mathrm{O}$ aberto e o fechado de uma e outra as tornam irreconciliáveis, pois a obrigação de exibir argumentos que possam ser contrastados por todos se opõe à pretensão de iluminação da profecia e o espaço na qual irrompe: o privilégio da revelação se dá na "intimidade do diálogo com Deus".

É patente que a religião da liberdade surge dos âmbitos da razão. 
No entanto, o caminho até a liberdade virtuosa, que implica na conversão do intelecto à "verdadeira" religião, tem uma implicação aparentemente paradoxal, a saber, que parece defender os direitos que possuem todos aqueles que não conquistaram os frutos da razão. Com efeito, a construção da liberdade geral consiste, simultaneamente, em uma limitação da influência dos prejuízos e em uma liberação da razão, porém, em não menor medida, também ampara os direitos que possuem todos aqueles que não reconhecem nenhuma autoridade em matéria religiosa, salvo as que subministra seu próprio juízo: “... chego à conclusão, já antes formulada: que se há de deixar a todo mundo a liberdade de opinião e o poder de interpretar os fundamentos da fé segundo seu juízo (itálico nosso) e que só pelas obras se deve julgar se a fé está segundo seu juízo, e que só pelas obras se deve julgar se a fé de cada um é sincera ou ímpia. Deste modo, todos poderão obedecer a Deus com liberdade e sinceridade, e só a justiça e a caridade merecerão a estima de todos" (Espinosa 3, prefácio, p.70). Não se deve compreender Espinosa como movido por uma espécie de culto intransigente à liberdade virtuosa, a dos homens prudentes; a defesa das liberdades hermenêuticas vale para todos que fazem uma interpretação livre dos livros sagrados como para todos aqueles que podem exibir seus contra-sensos. Tanto as hermenêuticas hegemônicas como as que são derivadas dos atos particulares de interpretação respondem à mesma paixão: considerar que suas pretensões são legítimas. Ao propor que os indivíduos sejam os legítimos intérpretes de sua relação com Deus, Espinosa desloca do centro da interpretação o princípio de autoridade. Não se trata, no entanto, de uma abdicação do pensamento espinosano de construir um mundo dirigido em função da virtude e da razão; trata-se, bem mais, de uma defesa da liberdade que, não havendo nascido da virtude, precisa ser justificada a partir das paixões e da subjetividade. Esse momento pelo qual a liberdade subjetiva parece superior frente à razão se coloca como uma etapa transitória para a cidade; inclusive se pode dizer que esta tese reforça com maior veemência a alegação espinosana a favor da liberdade: se as paixões justificam imperiosamente a liberdade, com maior determinação podem-no fazer a virtude e a razão.

\section{Alfakhar ou Maimônides}

$\mathrm{O}$ que fazer com as Escrituras? Assumi-las como um limite ou como um ponto de partida? Encontrar-se diretamente com seus dogmas ou deslocar-se até um fundo que espera ser encontrado pela razão? Ater-se a suas partes explícitas sem presumir que por trás delas há um conteúdo latente? Presumir sua consistência imediata? Dogmatismo e ceticismo se definem em função do poder que se atribui à razão frente à teologia; uns consideram que os fundamentos da fé podem ser vislumbrados pela razão e outros se fazem acompanhar da ideia de que as Escrituras contêm em si mesmas, sem outro auxílio que suas próprias forças, toda a verdade e, portanto, não é necessário ir mais além do que oferece sua letra. Espinosa denomina dogmatismo à disposição que quer que as Escrituras sejam guiadas por uma interpretação eminentemente racional; ao contrário, define o ceticismo como a doutrina pela qual a razão se submete integralmente às Escrituras, na qual esta modera e limita sua intervenção interpretativa. ${ }^{6}$ Uns querem averiguar o que há por trás da linguagem de parábola, outros querem aferrar-se à letra para assinalar que nelas se expressa inequivocamente a mensagem revelada. Essas duas perspectivas são personificadas em Maimônides e Alfakhar; ${ }^{7}$ essas duas figuras mantêm que a letra é ou um começo ou um limite para a razão. O intelectualismo dogmático ou o literalismo vulgar estão na origem de muitas das deformações que a religião possui, pois com Maimônides se 
problematizou onde não havia a necessidade de fazê-lo, com Alfakhar se consagraram todas aquelas opiniões que o vulgo da antiguidade professava. Aristóteles foi tomado como o estandarte da racionalização dogmática; o vulgo ávido de maravilhas é tomado como fonte e destinatário das revelações, o engenho que regula a redação e a predicação da Mensagem. Maimônides quer sofisticação intelectual onde Alfakhar quer condescender com o vulgo; porém o refinamento trapaceiro não é menos pernicioso que os prejuízos do vulgo de qualquer tempo e de qualquer lugar. Em ambas as perspectivas, Espinosa encontra espelhamentos e deformações: o literalismo toma as metáforas como verdades absolutas, assumindo sem exame e sem resistência as várias perspectivas que, sobre um mesmo tópico, possuem as Escrituras: a corporeidade de Deus, sua apresentação antropomórfica, o caráter da criação, sobre se tem movimentos locais ou se o céu é sua morada, etc.; ao contrário, o apelo à razão como instrumento de interpretação acaba por extraviar-se em um mar de sutilezas e de distinções que acabam por ser completamente estranhas ao objeto interpretado.

Os excessos da literalidade abriram a possibilidade de conceber uma imagem de Deus que ao longo de toda a Ética é criticada: as representações antropomórficas de Deus são a fonte da superstição e do integrismo que assumem que as Escrituras não apenas desenvolvem "modos de falar" como também verdades absolutas. Para Alfakhar a retórica bíblica não é só um meio expressivo senão o fundo mesmo da interpretação. Não há um sentido silencioso, porque a superfície é o fundo. O plano da expressão não oculta um infinito de significados obscuros porque eles aparecem determinados pontualmente pelos signos. A perspectiva de Alfakhar permite ler, porém impede de julgar. Essa leitura não permite remontar o que aparece na letra e renuncia a submeter, ponderar e comparar os diversos livros das Escrituras, quer dizer, se mostra incapaz de descobrir as contradições que há entre eles. Quem aceita tudo, sem nenhuma reticência, acaba por negar tudo. Prescindir em absoluto do juízo implica relativizar todas as passagens recorridas, pois aceitar tudo o que as escrituras aceitam e rechaçar tudo o que rechaçam é uma renúncia ao sentido comum. Prescinde-se, em poucas palavras, da lógica e se admite, sem nenhuma reserva sua pureza originária: Deus é zeloso e não zeloso, se move e não se move, o céu é um sólido e Deus não o é (Espinosa 3, XV, p.325). As antinomias do literalismo são as próprias do modo vulgar de representar-se as coisas. Assentir ou negar algo, essa atividade na qual vontade e entendimento coincidem, são os atos elementares pelos quais se apreende qualquer coisa. Espinosa ratifica essas teses da Ética nas quais se nega qualquer tipo de epoché - incluída a epoché hermenêutica, como a que pretende Alfakhar. Assim, pois, "é necessário servir-se do juízo e da razão para dar-lhe nosso assentimento" (Espinosa 3, XV, i, p.323). Alfakhar ignorou os ingenia (redatores diversos, públicos díspares, tempos heterogêneos) que intervieram para a confecção final das Escrituras. Aí onde o literalismo vê uma obra de uma só peça, na realidade se movem uma multiplicidade de fragmentos que respondiam a uma diversidade de fins, como, por exemplo, a predicação das escrituras e a necessidade de adaptá-las aos fins de conversão.

Em um sentido oposto, Maimônides se propôs a purificar as Escrituras das inconsistências, isso por uma virtude da razão. Na realidade, o que faz é "arrancar das Escrituras as bagatelas aristotélicas e suas próprias ficções" (Espinosa 3, p.83). Espinosa alude à autoridade dos filósofos, essa crença segundo a qual são donos da razão por chamar-se como se chamam, e não em virtude dos argumentos. Maimônides declarou a infalibilidade dos filósofos, e, ao fazê-lo, os transformou em pontífices. As ideias professadas pelo filósofo cordobês supõem que a interpretação deve levar-se ao ponto em que se exija a intervenção da filosofia como ferramenta interpretativa fundamental. A consequência dessa prática de sobreinterpretação é a confusão entre filosofia e teologia, que amiúde aparecem em sua obra 
como a mesma coisa: "Ele supõe, em primeiro lugar, que os profetas estiveram de acordo uns com os outros e que foram grandes filósofos e teólogos; porque pretende que eles tiraram conclusões a partir da verdade das coisas" (Espinosa 3, VII, iv, p.218). Ele privilegia o plano do conteúdo por sobre o plano da expressão e convoca a filosofia a arrancar significados mais além da letra. Espinosa o acusa de exigir das escrituras coisas que não se podem exigir delas e, por outro lado, de renunciar a explicar as coisas que deve explicar. Em que consiste pontificar uma opinião? Em substituir a letra pela interpretação, e, mais ainda, em enfatizar a eminência da interpretação e em torná-la um assunto de autoridade. Os pontífices sentenciam na cátedra e, ao mesmo tempo, legislam sobre crenças; nessa dupla função radica o perigo para a faculdade de julgar. A limitação dessa faculdade traz consigo a violência dogmática que limita e pretende suprimir um direito natural. Maimônides enfatizou não só o papel da autoridade no campo da interpretação, mas faz igualmente dessa autoridade uma forma de poder. Está fundada no pressuposto de que os indivíduos não têm direito a suas crenças e suas ideias. A pontificação da interpretação é algo mais que sutileza: é o ato a partir do qual se abre espaço ao dogmatismo religioso até seu posicionamento como supremo poder. A crítica a Maimônides conclui que "nem a teologia tem de servir à razão, nem a razão à teologia, pois cada uma possui seu domínio próprio: a razão, o reino da verdade e da sabedoria; a teologia, o reino da piedade e da obediência" (Espinosa 3, XV, iii, p.327). Assim como à razão não se pode exigir obediência, à teologia não se pode demandar lucidez: a restituição dos foros legítimos de cada uma delas é concludente no capítulo XV do Tratado Teológico-político; não se trata mais de estabelecer nexos de colaboração entre ambas, trata-se senão de reassumir o papel que cada uma tem. A piedade e a justiça não necessitam de sofismas nem de sutilezas, e sim, tanto mais, de um ânimo dócil. A conclusão é ainda mais vantajosa para a razão: não necessita sujeitar-se a nenhuma autoridade nem a cânone algum, pelo que a faculdade de julgar não tem de prestar contas a nenhuma instância exterior a ela mesma.

A tendência a fazer da religião algo acadêmico tem conseqüências não apenas para a própria sorte da religião, como também, sobretudo, para a vida social. Dessa disposição se desprendeu o gênio dogmático que começou por racionalizar a fé e acabou por legislar sobre opiniões e crenças; o dogmatismo não chegou às Escrituras antes que os filósofos começassem a incorporar sutilezas que formavam parte de tratados, porém não de revelações. A filosofia, unida às escrituras, contribuiu para interpretar de uma maneira cerrada os conteúdos da revelação e com isso contribuiu para estabelecer cânones rígidos controlados e administrados a partir das posições de poder. Os pontífices (sejam os fariseus ou os papas) estão investidos de uma autoridade que interpreta de uma maneira infalível e inequívoca. Daí que o caráter inquestionável de sua autoridade radique na eliminação do discernimento dos submetidos a sua autoridade. Quando o poder torna a interpretação absoluta, os limites da liberdade se tornam estreitos, pretende-se governar a faculdade de julgar e se promulgam leis que consagram um regime absoluto de crenças e persegue-se por razões de crenças e de ideias.

\section{Legisladores, profetas e doutores}

Porém a Espinosa não interessa apenas a chave pela qual a tradição interpretou as escrituras, mas ele também quer encontrar as que serviram para a redação de suas diversas partes. A compreensão das circunstâncias nas quais foram escritas subministram as explicações interpretativas que nela se desenvolvem: escrever para constituir um Estado, para revelar os éditos de Deus sobre sua condução ou em circunstâncias de decomposição 
social; tais são os diversos registros aos quais Espinosa remete cada um dos episódios de sua redação. O ordenamento e a depuração do cânone bíblico instituído pelos diversos concílios negligenciaram_a miscelânea de suas múltiplas intervenções, perspectivas de predicação e circunstâncias políticas e povos aos quais foi transmitido seu conteúdo; isso exige, na perspectiva espinosana, estabelecer os domínios aos quais pertencem seus diversos componentes. Para Espinosa as Escrituras não são sagradas por si mesmas, senão pela virtude que despertam. Daí que a idolatria à letra seja uma de suas mais fulminantes críticas: adorar à letra acabou por distrair da determinação de perseguir da melhor forma seu espírito. Quem corrompe a palavra de Deus? O homem de fé que prescinde das obras ou aquele que obra virtuosamente ainda que não tenha fé? Moisés mesmo se encarregou de romper com as tábuas da lei quando estas se haviam convertido em letra morta e seu povo havia retomado a idolatria prévia, quando deixaram de ser o testemunho da aliança. Daí que elas não tenham um significado em $s i$, apenas que as ações delas derivadas possam submeter-se ao juízo de piedade ou impiedade. Para Espinosa, são as ações que podem ser julgadas como profanas ou sagradas, não as crenças. A crítica bíblica espinosana se endereça a reconstruir chaves para ordenar o processo de criação textual a que correspondem seus dois grandes segmentos. O caráter sagrado das Escrituras já não repousa em seu autor, senão nas obras às que chamam seus ensinamentos. A Ética apresenta de uma maneira mais incisiva esta crítica à imagem mosaica de Deus, no mesmo sentido em que o Tratado teológico-político sustenta que "uma coisa é compreender a Escritura e a mente dos profetas e outra compreender a mente de Deus, quer dizer, a verdade mesma da coisa." (Espinosa 3, XII, ii, p.295) Assim, pois, esse tratado não se propõe a conhecer a natureza de Deus senão a organização interna das Escrituras e sua difusão como normas de vida.

As chaves tipológicas das Escrituras podem ser classificados em três grandes ramos: o legislativo, o profético e o doutoral. Os dois primeiros dominam a redação do Antigo Testamento, enquanto o terceiro seria a forma dominante do Novo Testamento. Não encontra nenhuma homogeneidade de tópicos e de tratamento ao longo de um livro que considera ter sofrido a intervenção de diversos autores, em tempos diversos e destinado a públicos heterogêneos. A revelação profética, a fundação de um Estado ou o conhecimento doutoral se remetem a fundamentos distintos: uma empresta a voz a uma mensagem que vem do mistério, outra instaura uma lei que pactua com Deus e a última nasce de um conhecimento que Espinosa interpreta como humano. Espinosa parece muito próximo à mensagem doutoral que possuem as escrituras. Suas afinidades intelectuais estão do lado de Salomão, Santiago e Mateus, reconhecidos por sua boa dose de bom senso, prudência e piedade. Sem embargo, o Tratado teológicopolítico possui a virtude de estabelecer as mecânicas da produção textual das partes que Espinosa apresenta de maneira crítica: não é o mesmo redigir para constituir um Estado (Moisés) e receber mensagens para ratificar a aliança do povo judeu (profetas) ou mesmo escrever em um momento de dissolução, com uma ótica doutoral e com um conteúdo especulativo e universal das coisas (Cristo e os apóstolos). Em que se reconhece um autor bíblico que fala como legislador? Fundamentalmente, o objeto de sua intervenção não são ideias de tipo universal senão a confecção de leis que permitam a fundação e conservação do Estado. Os limites desses textos radicam nas delimitações espaciais e temporais com que foram concebidos, quer dizer, como destinados especificamente a regular a vida política do povo judeu. Uma vez destruído esse Estado, perdem para Espinosa todo o sentido. A representação majestática de Deus tem, como conseqüência, um sentido mais imanente e mundano que transcendente e especulativo; Espinosa encontra nessa representação de Deus uma figura que responde mais à ideia de majestade política do que de um ser absolutamente infinito; 
o culto a Deus é o culto mesmo aos deveres frente ao Estado. Moisés encarna o protótipo do legislador cujas leis têm menos caráter de profecia que de constituição política: nos textos que lhe são atribuídos flutua com claridade a ideia de que o fundo da revelação são as coisas práticas mais que as que possuem um conteúdo dogmático. Ali onde alguns intérpretes vêem, no Pentateuco, a criação cósmica, Espinosa encontra a semente da formação do Estado hebreu. O fundo ao qual se deve atender nos escritos de Moisés são os preceitos ético-políticos: a veneração a Deus é a chave fundamental para entender um Estado teocraticamente fundado. Daí que a imagem constante de Deus seja a de um príncipe dotado de uma vontade que se altera, que governa o mundo segundo decretos, absolve e condena. Uma vez liberados da sujeição ao Egito e recuperados todos os direitos naturais, se tornou necessário estabelecer as leis às quais se sujeitariam e transferir todo o seu direito a um homem, a um grupo de notáveis, a uma multidão ou a Deus.

Submeter um povo ao governo de Deus implica estabelecer o vínculo de comunicação com o sobrenatural. Espinosa descreve o primeiro pacto como uma democracia em que todos os membros da comunidade podiam consultar Deus sem mediação alguma. Apesar disso, o primeiro pacto termina em razão do temor pelo numinoso, o temor de escutá-lo e de perecer deu lugar à legitimidade de Moisés, o único membro da comunidade dotado da capacidade de escutá-lo sem ser abatido pelo transcendente. Destruído o primeiro pacto de caráter democrático em virtude do temor a Deus, o segundo confere a Moisés o papel de um "oráculo divino" (Espinosa 3, XVII, ii, p.362). Os dogmas estabelecidos por Moisés são religiosos, ao mesmo tempo em que são leis civis, mesma relação das cerimônias religiosas com as cerimônias cívicas. Assim, pois, o emaranhado de religião e de direito repousa sobre um Estado constituído em função da obediência a Deus. A legitimidade do poder depositado em
Moisés radica somente no monopólio da interpretação dos ditos e direitos de Deus; dessa maneira, Moisés não é concebido como um legislador que, através da razão e do consenso, pode fundar o direito da cidade. Moisés não se distingue dos profetas no que se refere a "consultar a Deus"; sua diferença radica na ordem dos fins pelos quais se estabelece essa comunicação, pois se movem, tais fins, na ordem das relações de obediência entre Deus e o povo de Israel. Trata-se de um intérprete que, diferentemente dos grandes profetas, não especula sobre as coisas sobrenaturais; sua tarefa estava focada, pela perspectiva de Espinosa, na salvação do Estado. As sucessivas destruições do Templo de Jerusalém e o cativeiro a que foram submetidos os israelitas assinalam as limitações temporais da lei de Moisés. A validez desta depende exclusivamente da existência do Estado.

Por sua parte, a profecia é uma interpretação de todas aquelas coisas que a razão não consegue explicar. Fundamenta-se na fé, pois seu sentido radica na aceitação passiva dos mistérios. A narrativa profética faz incursão nos lados obscuros de Deus e se desdobra sobre os signos e vestígios que lança sobre o mundo. Os sonhos e visões formam parte de toda a série de fenômenos aos quais se referem as interpretações da vontade de Deus. Está claro que, para Espinosa, a chave de geração textual a que responde a maioria das partes do Antigo Testamento se pode classificar sob essa categoria, como surgida à margem da razão, como determinada pela imaginação que se consome em signos e que impõe a essas partes um significado arbitrário. Como se reconhece a autoridade de um profeta? Da presunção de um vínculo com a vontade de Deus. A relação vis-à-vis que estabelece nesse escrutínio se desenvolve através dos signos, de fenômenos naturais, de vestígios, quer dizer, pertence à ordem da imaginação. A sondagem da vontade de Deus é um objeto de interpretação que requer uma capacidade sobrenatural e sobre-humana para escutar sua voz: "se não queremos forçar a Escritura, há de se conceder, sem mais, que 
os israelitas ouviram uma voz verdadeira, já que ela disse expressamente (Deuteronômio, 5, 4): Deus falou cara a cara com vós, etc., quer dizer, igual a dois homens que queiram comunicar-se mutuamente conceitos, mediante os corpos de ambos.” (Espinosa 3, I, ii, p.79) Quando Espinosa sustenta que a profecia supõe uma relação corporal entre o emissor da mensagem e aquilo que ele transmite, está assinalando que se trata de uma experiência sensível, não intelectual. A profecia se explica desde os ingenia que mobilizam as percepções dos profetas, quer dizer, está referida a um conjunto de dispositivos anímicos que impulsionam determinadas visões. Respondem, portanto, a estados de "iluminação" estritamente privados, bem além da constatação pública da experiência. A profecia é, portanto, uma das formas de afecção do corpo e uma experiência que passa pela linguagem. As palavras e os signos de indexação a partir dos quais se formula uma ideia da vontade de Deus têm lugar em uma forma de conhecimento na qual não há nenhuma explicação do tipo causal; daí os equívocos a que dá lugar o significado de uma experiência como as chamadas proféticas. Os signos de indexação e as palavras, diferentemente da ideias, não podem ser ordenadas causalmente. A categoria de ordem pertence ao conhecimento, porém não de profecia: uma experiência dessa classe não é ordenada nem pode ser traduzida em termos de ordem. Se não há ordem, há imperativos. A profecia é um instrumento disciplinar, na medida em que, qualquer que seja o conteúdo dela, sempre convoca a submeter-se à vontade de Deus. A obediência pela obediência se chama fé. A aceitação passiva dos mistérios consiste em uma renúncia explícita à problematização do conteúdo da revelação: a faculdade de julgar as coisas a partir de si mesmo está excluída da ordem das proposições de caráter imperativo que nela dominam. Deus sentencia, ordena, julga e os homens calam e obedecem. As profecias são feitas mais em função do espírito de rebanho que de individualidade: convocam os povos a submeter-se aos princípios sobre os quais se fundaram seus cimentos políticos, religiosos e culturais.

Em troca, a autoridade dos apóstolos não radica na edificação de leis. A natureza dos textos do Novo Testamento, ao ser de ordem especulativa, está submetida a divergências de fundamentação da religião. As duas posturas fundamentais nas quais se sedimenta a ideia de religião no Novo Testamento são as que estão no princípio de muitas das disputas teológicas do cristianismo: ou bem se fundamenta a religião na fé, ou bem nas obras. A importância da fundamentação da religião radica no fato de que dela se deriva ou a possibilidade de dirigi-la até a ordem da limitação das ações externas, quer dizer, que governe e limite a ordem dos afetos sociais, ou bem até a ordem dos foros subjetivos de cada indivíduo e, assim, tutele todas as suas crenças. Espinosa explica o mundo antigo como aquele no qual a religião é a lei da pátria. ${ }^{8} \mathrm{O}$ advento de Cristo tornou ecumênica a lei de Deus e rompeu com a delimitação temporal, espacial e política da lei mosaica. Com efeito, a delimitação entre a lei dos judeus e a palavra de Deus difundida universalmente confere às Escrituras um caráter supranacional e confere uma personalidade mais racional ao objeto dessa sabedoria. O Novo Testamento não expressa os elementos da aliança entre Deus e um povo e lhe dá um conteúdo que, em primeira instância, não é político. Os ensinamentos do Novo Testamento têm um caráter moral e têm uma origem doutoral, correspondem a um tipo de sabedoria que está fincada em meios e fins humanos. A diferença entre os evangelhos e o Antigo Testamento consiste igualmente no meio pelo qual se vincula Deus aos homens: "se Moisés falava com Deus cara a cara, como um homem fala com seu companheiro (quer dizer, mediante dois corpos), Cristo se comunicou com Deus alma a alma" (Espinosa 3, I, ii, p.85). Essa relação de alma a alma é aquela que freqüentemente tem sido interpretada como a prova patente de que Espinosa eleva o registro desse vínculo a um nível 
que a Ética denomina ciência intuitiva. O conteúdo dos textos de origem doutoral está dirigido ao “ânimo interno”, quer dizer, a inspirar o sentimento de piedade e justiça.

Cristo não foi um profeta armado nem desarmado; tratou-se de um dos mais altos sábios do mundo antigo, inclusive Espinosa o identifica como um modo infinito do pensamento de Deus. Teve essa disjunção, porém não elegeu ser uma coisa nem outra; converteu-se em um pensador da crise e dissolução da cidade, porém suas ideias se distinguem das revelações de Moisés na medida em que vão mais além da opressão local e anunciam uma liberação que não é apenas política. O contexto no qual se desenvolveram os evangelhos foi aquele de uma decomposição dos fundamentos da justiça, uma sabedoria que se levanta em épocas de opressão e que se funda no mais alto sentido da fraternidade humana. Um Cristo doutoral que alcança o terceiro grau de conhecimento? Porém não apenas Cristo é concebido como autor de uma sabedoria que versa sobre o bem viver; também os apóstolos são concebidos como personalidades que recolhem o testemunho dos ensinamentos de Cristo, além de que eles mesmos podem ser concebidos como partícipes ativos de uma indagação de ordem moral: "Paulo fala segundo seu próprio parecer" (Espinosa 3, XI, i, p.278). Dessa perspectiva, podem ser considerados autores e não um simples veículo de uma mensagem que os transcende. Os evangelhos têm uma perspectiva humana na qual há um vínculo de responsabilidade com o que se diz, eles retêm a personalidade do autor. Essa é uma das possíveis interpretações do alcance intelectual dos evangelhos. ${ }^{9}$ Espinosa prescinde da ideia antropomórfica de um filho de Deus para concebê-lo como um entendimento puro, como uma encarnação mesmo da ideia de Deus. Surgidos à margem da revelação, os evangelhos não representam nenhum poder sobrenatural nem encontram seu suporte na presunção de ser o produto de uma palavra transcendente.

\section{A lógica da ilusão}

É fundamental, para a interpretação dos tratados políticos de Espinosa, particularizar a perspectiva a partir da qual ele se propõe interpretar os livros sagrados. Não projeta encontrar neles mistérios e chaves para a interpretação da presença de Deus no mundo. A busca pelo conteúdo interior da religião o leva de maneira indefectível a exibir como os verdadeiros fundamentos desta estão na prática da caridade e da justiça. Dizer que os ensinamentos dos livros sagrados se reduz a questões do tipo prático implica admitir que todas as questões reveladas não formam parte da ordem das verdades eternas, sim da confusão derivada do delírio profético. Por momentos, Espinosa parece assumir abertamente que, para possuir virtudes, não se requer nada da revelação; que para conter as paixões não basta o poder da religião. Inclusive chega a afirmar que as religiões são uma pródiga fonte dessas paixões: produzem mais paixões do que as revogam. No entanto, essa perspectiva hermenêutica não se reduz à apresentação das fontes da antiga escravidão e dos novos prejuízos; propõe-se a encontrar na prática das diversas religiões uma fonte de conflitos propiciados pela diversidade de concepções do mundo e, ao mesmo tempo, uma solução libertária à presença desses conflitos na esfera da vida pública. Nesse conflito subjetivo, a razão não é nem um contendor nem árbitro. Sustenta que, se a razão é o único meio para encontrar o soberano bem da sociedade política, estará por cima das contendas de tipo religioso, que as religiões tradicionais não são um instrumento para a concórdia e que, à falta de juízo, convém fazer uso de um instrumento que não é a razão, porém que é racional: a tolerância.

Cabe esperar de um espírito racionalista uma atitude pluralista e, ao mesmo tempo, assumir que constituem a razão unicamente as verdades necessárias e incontroversas das demonstrações da alma? Ainda que resulte 
numa colocação paradoxal, o espinosismo pode se fincar em ambas as perspectivas. $\mathrm{O}$ fato de que aceite o pluralismo como uma espécie de "moral provisória" não o impede de formular as demandas urgentes da razão. ${ }^{10}$ A compreensão da imaginação está formulada precisamente como uma ausência de critério, como uma condição na qual a alma não tem uma pauta para julgar as coisas; se algo comporta a razão, a alma é um instrumento para taxar de maneira constante a consistência das coisas. Ter um critério firme consiste em compreender as questões que ocorrem aos homens de acordo com um cânone metodológico, pois a força da superstição consiste em que a oscilação das opiniões é produto de um intelecto arrastado em diversas direções, pelas mais heterogêneas e desencontradas ideias que subministra a imaginação. Submeter as questões a um cânone da razão consiste em julgar de acordo com a estável execução dos procedimentos desta. Em sentido inverso obram as forças dos afetos: eles são a primeira força de resistência à estabilidade do juízo que obra conforme as regras. Espinosa e seus contemporâneos atribuíram à esperança e ao medo a acusação mais tenaz, com o fim de combater energicamente as mitologias derivadas da superstição. A maré das opiniões desloca a alma por todos os registros mais fecundos da imaginação; o delírio se opõe à razão não apenas porque está disposto a crer em qualquer coisa; poderíamos agregar que o método é o sedimento pelo qual se encontram em uma plataforma sólida todas as ideias do entendimento: "Se os homens pudessem conduzir todos os seus assuntos segundo um critério firme, ou se a fortuna lhes fosse sempre favorável, nunca seriam vítimas da superstição" (Espinosa 3. prefácio, p.61). Com uma espécie de estoicismo asseado pela razão, Espinosa costumava expor os prolegômenos de suas obras aludindo à contraposição que suscitam as paixões geradas pela fortuna frente às prevenidas ideias de uma alma assentada sobre a solidez dos critérios. Julgar as coisas a partir das circunstâncias da fortuna, quer dizer, a partir das flutuações que possui nossa esperança frente às promessas do futuro, consiste em despojar de fundamento todas as coisas que se podem conhecer; nem a natureza nem a razão podem ser consideradas adictas do extraordinário. A perda de proporção sobre as causas das coisas se torna para Espinosa o alimento a que mais recorre a ignorância.

A lógica da ilusão fica exposta a partir de observações dirigidas pelo propósito de construir uma espécie de "ciência da natureza humana". Não se pode omitir em toda compreensão íntegra sobre os mecanismos da superstição humana que um dos seus suportes mais poderosos constituí a própria natureza do homem: a incerteza e a ignorância da verdadeira ordem das coisas se ostentam como os motivos mais assíduos da superstição. Essa lógica pode ser explicada por três momentos chaves: a) a inconstância no ânimo e nas opiniões; b) exibindo suas origens; c) mostrando as formas pelas quais se arraiga na vida social. O ânimo sobre o qual se implantam as mais severas superstições está submetido à força das coisas exteriores e é arrastado pelos fluxos encontrados que revolvem a imaginação e que o impedem de seguir com claridade o curso das causas. No contexto explicativo da ciência da natureza humana, o desejo ocupa um lugar que não está qualificado senão em função das potencias das quais se faz acompanhar. Se o desejo se turva com a imaginação, sua tendência será inevitavelmente supersticiosa; se se faz acompanhar dos recursos das ideias, sua inclinação se verá determinada à afirmação virtuosa da alma. Não há moderação, prudência e Constancia de ânimo que logrem contrapor-se por si mesmos aos excessos de um desejo assenhorado pela imaginação. A virtude e a claridade para ver a natureza das coisas provêm da mesma fonte, porém Espinosa não crê que possa haver ação virtuosa que ao mesmo tempo não contenha a capacidade para ver com claridade a ordem das coisas. No Tratado Teológico-político, Espinosa está empenhado em mostrar que na origem da superstição se encontram associados um desejo incontinente 
e uma imaginação excitada: "Precisamente por isso, constatamos que os mais aferrados a todo tipo de superstição são os que desejam sem medida coisas incertas; e vemos que todos, muito especialmente quando se acham em perigo e não podem defender-se por si mesmos, imploram o auxílio divino com súplicas e lágrimas..."(Espinosa 3, prefácio, p.62). ${ }^{11}$ A demarcação a que se propõe Espinosa localiza, por um lado, as fontes imaginárias da superstição e, por outro lado, as fontes racionais com que um intelecto percebe as regularidades que compõem a ordem da natureza, unida à convicção de que "suprimida a ignorância, se suprime também o estupor"(Espinosa 2, I, apêndice, p.71).

Assim, pois, a superstição é originada pelo desejo e conservada pelo temor. As superstições se arraigam com maior vigor ali onde há ignorância: o temor contribui para alimentar sua continuidade. Ora, Espinosa não desconhece que é parte constitutiva da natureza humana essa paixão; a humanidade do temor não é, porém, condição a que se resigna sem resistência. $\mathrm{O}$ caráter reformador da filosofia de Espinosa se põe à prova frente a essa classe de obstáculos que impedem que o homem se vincule com as partes mais ativas de sua alma. A razão suficiente do surgimento e da persistência da superstição, apesar de constituir uma parte da natureza humana, não é uma fatalidade, salvo que os regimes políticos baseados em uma obediência passiva e tirânica se empenham em fomentar essas causas. Por isso, Espinosa exibe o Estado democrático e republicano como o portador dos valores libertários, como o único que é capaz de estabelecer as condições a partir das quais se podem suprimir do espaço da vida social o temor e a esperança. São tarefas da razão a derrota de todas as formas de tirania e os supostos passionais nos quais se sustenta. Para avançar até um exercício virtuoso e ilustrado da liberdade se precisa, por uma dupla partida, de condições externas favoráveis - as que subministra uma sociedade democrática - e das condições que comporta o próprio intelecto. Na medida em que impõe o dever da ilustração tanto ao Estado como aos indivíduos, assume que antes de consumar a liberdade esta tem que transitar pelos campos do prejuízo. Com efeito, a liberdade se exerce, de maneira primária, em um mundo dominado pelos prejuízos.

Uma nota destacável é o fato de que a liberdade apareça unida à explicação espinosana sobre os prejuízos. A leitura mais óbvia sobre essa relação seria que a liberdade se opõe necessariamente aos prejuízos e à superstição. No entanto, o propósito de Espinosa não está exclusivamente orientado e desterrá-los. A conseqüência principal do questionamento de Espinosa é que não se pode pensar seriamente a natureza deles sem exibir as relações que guardam com a liberdade. Não é que Espinosa admita que a liberdade se fundamenta nos prejuízos; melhor, pensa essas partes obscuras do entendimento humano no marco de uma espécie de trégua da razão: por meio dela demanda que a vida social admita um horizonte plural de religiões e de concepções de mundo. Os prejuízos não são combatidos por outros prejuízos, apenas a liberdade permite superar seus limites estreitos. Um marco de liberdades subjetivas pode admitir os membros de uma sociedade como donos legítimos de todos os seus prejuízos. Porém os prejuízos vinculados ao poder não têm a capacidade de incluir uns nos outros. O que defende Espinosa é o caráter inclusivo da liberdade, não os prejuízos enquanto tais. O prejuízo é um correlato da liberdade, no mesmo sentido em que para Descartes a liberdade é correlata do erro: só erra aquele que possui liberdade. Espinosa parece disposto a pôr a liberdade por cima da consideração acerca de se o homem é servo de suas paixões ou um ser racional. Não importa o estofo intelectual de que cada indivíduo está dotado: o que realmente importa é que os prejuízos não podem limitar-se a partir dos âmbitos do poder. O campo das neutralizações subjetivas que estabelece tem também alcance para todas as igrejas; isto implica despojálas de todo privilégio, quer dizer, de seu caráter iluminado em torno da 
interpretação.

Na medida em que a exegese das Escrituras está dirigida a mostrar que o Estado não perde estabilidade negando-se a interferir no campo dos direitos subjetivos, Espinosa arremata essas exposições sustentando que a substância fundamental da coisa pública é a liberdade. Não conclui que o exercício dos direitos com os quais a natureza dota os indivíduos seja um motivo para as rupturas na ordem social; os direitos subjetivos são um bem soberano: no campo da vida social, igualmente ao campo da vida ética, tudo o que é virtude tende à afirmação e à fundação instituinte. A liberdade edifica mais do que quebranta. A paz não pode estar assentada sobre a submissão das consciências, sim sobre o reconhecimento de que todas as formas de culto têm lugar na cidade. Nas primeiras páginas do Tratado Teológico-político fala-se da liberdade como uma espécie de concessão; sabemos que Espinosa não a assume, em última instância, como uma mera forma de capitular em suas atribuições. A tese mais radical sobre a natureza da liberdade está colocada em função da impossibilidade que tem o Estado para controlar todas as coisas relativas à consciência: a gratuidade da liberdade não pode deslindar-se de uma concepção sobre os limites da autoridade e dos direitos dos indivíduos. Não é uma concessão senão uma condição natural no homem. O filósofo acaba por concluir que em matéria de liberdade não apenas não é possível não concedê-la como, mais ainda, é perigoso que se assuma como poder que pode limitá-la: o preço dessa limitação é a paz..$^{12}$ A realização da liberdade como ratio última do Estado consiste, em primeiro lugar, em renunciar à pretensão de delimitá-la; em segundo lugar, consistiria em promover ativamente todos os meios ilustrados para conquistar uma liberdade que amadureça como fruto da razão. Em relação à primeira fase da liberdade, o processo é acompanhado pela tolerância; a segunda fórmula se desdobre a partir da virtude republicana. Seja por uma visão ativa, seja por um exercício passivo, a liberdade é o único meio pelo qual os homens de uma comunidade podem se consagrar à paz. Pelo contrário, institucionalizando os prejuízos, a autoridade se aplica à perseguição. Discorrendo sobre essa matéria, Espinosa não dissimula sua crítica aos regimes monárquicos; todos eles baseiam a estabilidade na superstição. Nas palavras seguintes, Espinosa parece antecipar tanto a Rousseau como a Montesquieu:

\begin{abstract}
"Ora, o grande segredo do regime monárquico e seu máximo interesse consistem em manter enganados os homens e em disfarçar sob o especioso nome de religião o medo com o qual se quer controlá-los, a fim de que lutem por sua escravidão como se se tratasse de sua salvação (grifo do autor), e não considerem uma ignomínia, senão a máxima honra, dar seu sangue e sua alma para o orgulho de um só homem. Pelo contrário, em um Estado livre não caberia imaginar nem empreender nada mais desditado, já que é totalmente contrário à liberdade de todos assenhorar-se do livre juízo de cada qual mediante prejuízos ou coagi-lo de qualquer forma. E quanto às sedições, suscitadas com o pretexto da religião, surgem exclusivamente porque se dão leis sobre questões teóricas e porque as opiniões - igualmente aos crimes - são julgadas e condenadas como delito. A verdade é que seus defensores e simpatizantes não são imolados para a salvação pública, e sim tão somente para o ódio e a crueldade de seus adversários. Pois se o Estado estabelecesse por lei que só se perseguissem os atos e que as palavras fossem impunes, não caberia disfarçar tais sedições de nenhum tipo de direito, nem as controvérsias se transformariam em sedições." (Espinosa 3, prefácio, p.64-65)
\end{abstract}

Levado em conta que os princípios da religião não podem ser interpretados de maneira inequívoca, é impossível evitar que as opiniões 
se multipliquem. A imaginação tende, por natureza, ao pluralismo; a razão é uma, a imaginação se bate em diversas direções e constitui uma multidão de tendências subjetivas: "há tantas opiniões como cabeças, cada qual abunda em seu próprio sentir, as discrepâncias entre os cérebros não são menores que entre os paladares. Esses ditos bastam para mostrar que os homens julgam as coisas segundo a disposição do seu cérebro e que mais as imaginam que as entendem" (Espinosa 2, I, apêndice, p.76). Adorar a Deus como a cada um lhe agrade é a base de uma liberdade republicana construída sobre a base da tolerância, mesmo que não necessariamente sedimentada em princípios racionais. Inclusive a lei revelada, para já não mais falarmos da lei natural, deixa a liberdade de cada um, de acordo com os poderes de seu intelecto ou com a impotência de sua imaginação, poder resolver sua vida intelectual ou religiosa. Não se pode ignorar que a defesa da tolerância implica uma certa atitude pessimista; a base de sua defesa contém o suposto de que nem todos os homens podem se despojar do véu da ignorância. Não poucas vezes, Espinosa deve ter se colocado um problema típico da filosofia política, o que fazer com os ignorantes nos quais se arraigam todas as superstições? Um remédio exterior sempre tem sido, para um pensador da liberdade, admitir sua existência na cidade e renunciar a fazer dela o lugar da comunhão dos santos. O outro remédio é a educação, e essa é uma tarefa que a razão teria que empreender para assegurar o advento da liberdade virtuosa.

A chave interpretativa da qual parte Espinosa não consiste em seguir de maneira imanente os conteúdos das Escrituras. Sua perspectiva metodológica pode ser compreendida como uma reconstrução crítica e não, como seria a perspectiva privilegiada pela Ética, construtiva e demonstrativa. Esse método representa o capítulo espinosano sobre a disputa fides-ratio que se encontra presente em muitos pensadores modernos. Ao não promover as causas obscuras da imaginação, pretende levantar um procedimento de análise no qual se evite todas as armadilhas estendidas por seus interesses. Desautorizados no nível intelectual, o reduto no qual as Escrituras possuem uma influência indubitável pertence à ordem da vida moral. Há um Espinosa genealogista que se propõe a exibir os verdadeiros fins da profecia:

"Estes são, pois, os pensamentos que me embargavam: que a luz natural não só é depreciada, como muitos a condenam como fonte de impiedades; que as elucubrações humanas são tomadas por ensinamentos divinos, e a credulidade por fé, que as controvérsias dos filósofos são debatidas com grande paixão na igreja e na Corte, e que daí nascem os mais cruéis ódios e dissensões... à vista disso, decidi examinar de novo, com toda a sinceridade e liberdade, a Escritura e não atribuir a ela nem admitir como doutrina sua nada que ela não ensine com a máxima claridade... Guiado por essa cautela, elaborei um método para interpretar os sagrados volumes"(Espinosa 3, prefácio, p.68).

Que a profecia esteja mais vinculada à vida prática que à espiritual permite a Espinosa formular a tese segundo a qual o sentido último das profecias se move no sentido do ensinamento de questões relativas ao espaço político e moral. O mito do povo eleito e o do carisma profético ficam reduzidos ao âmbito da explicação histórica: a edificação do Estado de Israel e a consideração de que a piedade é o que motiva o sentimento profético. Em ambos os casos não há “eleitos" e sim homens impulsionados a atuar em função de coisas humanas, no entanto protegidos pela aureola da divindade de suas opiniões. Ele encontra que o imperativo mais urgente que move o entusiasmo profético é um que também o possui a razão - a fundação de instituições, leis e critérios -, que, entretanto, realiza-o por 
outros meios: as ações de fundação são a finalidade, a justificação espiritual provendo o dogma da revelação que pretende que Deus tem um pacto privilegiado com o povo de Israel. O que o entendimento averigua, ali onde põe em tensão todas as suas forças, é que os fins da profecia radicam em uma tarefa mundana.

De acordo com as pautas hermenêuticas que segue Espinosa, não há a pretensão de voltar-se sobre a tradição para justificá-la, senão exibir nela todos os sedimentos irracionais que persistem no presente. No século de Espinosa, já não havia nem profecias nem profetas, porém havia ministros de cultos e sectários com poder. Acudir à tradição implica exibir nas diversas formas da religiosidade vestígios da antiga escravidão. Vincula sua percepção do passado - particularmente o do povo hebreu - com a escravidão e a irracionalidade de uma comunidade que vive a infância de sua organização como Estado. Viajar à semente do prejuízo e da superstição implica descobrir na escravidão dos antigos os fundamentos da servidão do presente; nessa classe de perspectiva não se pode esperar que o vínculo com a tradição seja, à maneira como professam os hermeneutas de nossos dias, um "diálogo com a alteridade"; a tradição é a fonte dos prejuízos e das servidões. O comportamento do vulgo não está longe, de acordo com o exame de Espinosa, dos prejuízos dos escravos da antiguidade. A religião que é desnudada com a crítica de Espinosa é a que se expressa em formas puramente exteriores e que em nada contribui para a formação do ânimo dos cidadãos; se converte em religião da servidão tudo o que ofereça asilo à ignorância, que preserve a vestimenta puramente exterior - ritos, narrações e costumes - e prescinda das partes ativas que havia nela. As tradições a que remonta a filosofia de Espinosa não são objeto de nenhuma reivindicação, sim de um severo escrutínio: justifica-as como práticas de religiosidade primitiva, porém não como ensinamentos dirigidos ao exercício da virtude.

\section{A liberação da faculdade de julgar}

A faculdade de julgar não constitui um gênero de conhecimento, no sentido em que a Ética e o Tratado da reforma do entendimento o concebem. A faculdade de julgar raramente alcança as alturas do raciocínio, não se guia geometricamente nem se constrói articulando as proposições segundo a ordem das razões. O edifício do conhecimento requer algo mais que uma boa dose de sentido comum; daí que Espinosa sustente que "ainda que não possamos demonstrar matematicamente esse fundamento de toda teologia e Escritura, podemos aceitá-lo com juízo são." (Espinosa 3, XV, iii, p.330). Julgar com juízo são não é, pois, conhecer de acordo com um procedimento construído segundo uma regra. A faculdade de julgar não tem por objeto aquilo que a razão pode investigar, pois seu papel é mais negativo: se desenvolve sobre a ordem das coisas que se podem aceitar sem acreditar que são representações racionais, e que, mesmo assim, são inofensivas para a vida em comum. O registro a que pertencia o bom juízo é o da certeza moral, que Espinosa distingue rigorosamente da certeza matemática, "se equivocam, pois, totalmente de caminho aqueles que se empenham em demonstrar a autoridade da Escritura com argumentos matemáticos" (Espinosa 3, XV, iii, p.229). As crenças que se professam em uma comunidade formam parte do índice de matérias a que se refere o "juízo são". À falta da geometria, basta uma boa cota de cautela e de boas obras? Talvez sim. Em todo caso, Espinosa está convencido de que os dogmas não podem servir para orientar a faculdade de julgar, pois a prova crucial do bom juízo não reside no que se crê e sim no que se faz. Assim, pois, o bom juízo tende a deslocar as questões teóricas e dogmáticas do que se pode denominar de uma atitude de discernimento não ilustrado.

Porém, além de considerar essa questão em relação ao juízo sobre o conteúdo de um livro em particular, Espinosa interpreta a faculdade 
de julgar como um poder do qual está dotado todo indivíduo, uma vis nativa que constitui o espaço subjetivo de todo indivíduo. Remete-se à ordem daquelas coisas irrenunciáveis que são constitutivas de cada um, não uma simples atividade assessória daquela que se pode transferir como se fosse uma letra de câmbio endossável. A faculdade de julgar, ativa ou passivamente, está presente em todos os homens, ainda que não esteja disciplinada por nenhuma espécie de método; trata-se de um nicho no qual não há nenhuma autoridade que esteja por cima dos indivíduos. Essa faculdade, pela qual cada indivíduo pode submeter a seu próprio critério as coisas sagradas e profanas, é a expressão mesma da liberdade: essa liberdade não lhe acontece, nem é recebida do exterior, não é concedida e não se priva, daí a inutilidade de legislá-la, limitá-la ou invalidá-la. Está antes e depois do poder, daí que o Estado que renuncia a pontificar seja o menos violento. Permanece inalterável; permanece aí mesmo que não seja consentida por um poder arbitrário; permanece por cima das duas formas de debilitá-la, o temor e a esperança. Constituindo-se como um limite para o poder, a faculdade de julgar cumpre com uma tarefa da natureza humana, a de pensar além dos constrangimentos e dos limites externos violentos. Inclusive nas condições mais precárias de sua existência, acaba por se confirmar como uma esfera que está por cima de todo poder. A racionalidade tampouco pode entender-se como uma "propriedade do príncipe", por exemplo, o filósofo-rei de Platão, salvo na racionalidade do pacto social. A partir disso é questionado o princípio da autoridade: a "verdade" não é propriedade da autoridade (filosófica ou política, ou as duas juntas como queria Platão), sim uma propriedade da razão. Esse projeto da modernidade não apenas consistiu em levar à sua maior crise os princípios lógico-argumentativos do aristotelismo, como também à crítica de seu conceito mesmo de sociedade política. A liberdade de pensar deve ser colocada como um intento de subtrair esta do princípio de autoridade e como algo alheio aos fins da ação da cidade. Não apenas se trata de um impedimento da cidade como de um limite positivo ao conteúdo de sua ação. Seu significado é, como já indicamos, ambíguo. Se estivesse no poder do Estado o controle da consciência, não só seria legítimo como seria um imperativo; porém o Estado não pode fazê-lo e por isso não tem direito a isso. Por essa razão a liberdade de pensar não pode ser entendida como uma concessão do Estado a seus associados, sim como um limite. Espinosa sabia que nenhum Estado democraticamente constituído pode ser lesionado pelas palavras. A violência ou a moderação frente à faculdade de julgar proporcionava o critério mais forte para delimitar uma ordem concebida a partir do respeito à liberdade mais fundamental da natureza humana. A moderação, que é a forma de virtude política mais elogiada pelos modernos, está dirigida fundamentalmente para o respeito de todos aqueles direitos dos quais está investida a natureza humana e que constituem os limites da intervenção do poder. Moderação é moderação frente às palavras e juízos dos indivíduos. Apesar de ser possível usar o poder para fins contrários à utilidade pública, Espinosa não menosprezou o valor que possuem os limites para seu exercício, pois se trata, antes de tudo, de um imperativo para os que detêm o poder e para os cidadãos que exercem um direito. Não é que Espinosa sustente que a faculdade de julgar não tem limites, apenas que esta não pode ser eliminada. A moderação não está prescrita em nenhuma lei; pertence ao âmbito das coisas que correspondem ser guiadas pelo bom sentido. Tanto os tiranos como o vulgo são extremamente perigosos para a liberdade: a soberba para mandar e a humildade para obedecer se sustentam em posições que estão acima de toda prudência. $\mathrm{O}$ vulgo não exerce como tal a faculdade de julgar, apenas sua vontade de maravilhar-se no insólito; os tiranos exercem o poder violentamente pretendendo sujeitar ao poder coisas que estão acima de seu alcance. À força do bom juízo, Espinosa quer que o vulgo não seja mais vulgo e que os tiranos deixem de sê-lo; 
uns devem renunciar à pretensão de seus palavreados e outros a dominar uma matéria que escapa ao poder. A tolerância fundaria uma ordem não autoritária na medida em que esta consistisse no reconhecimento dentro do pacto social não da unanimidade ou da oficialização de uma crença, sim no reconhecimento da complexidade do tecido social e, portanto, da pluralidade de sua composição. ${ }^{13}$ A integridade e a soberania do Estado não consistiriam então na homogeneidade das crenças, sim na compatibilidade racional de todas elas em uma mesma entidade soberana.

Dessa maneira, o mais alto direito natural se alcança e se constitui sob a égide da sociedade política: portanto tampouco se poderia, em sentido estrito, dizer que a sociedade política consiste em renunciar a este direito senão constituí-lo, não o criar, sim sacrificá-lo em favor do Estado. Então por que se pode pensar o direito de pensar livremente como um direito natural? Aparentemente esse direito não se dá no estado de natureza, porém se conserva como se fosse um direito natural. $\mathrm{O}$ direito ao pensamento livre se diz em relação ao todo social, frente às crenças e frente à sociedade política. Da mesma maneira que a liberdade se diz apenas em relação à sociedade política, o direito de se pensar livremente se diz em função do âmbito das ideias e das crenças que formam o mundo de supostos fundamentos da sociedade política. O objeto da intervenção teórica do espinosismo consiste em evitar que a politização do temor e da esperança tenha alcances subjetivos; daí que defina o direito como aquilo que tem por objeto todas aquelas ações que rebaixam os foros da subjetividade. Um sentido coerente do direito começa por definir o que pode ser governado e limitado, todo aquele conjunto de coisas que os membros de uma comunidade política elevam à qualidade de interdito e as coisas a que explicitamente renunciam, como provocar danos a terceiros e ao próprio Estado. Sobre a faculdade de atuar recaem todas as limitações que os cidadãos se impõem. A politização do medo e da esperança que se abre novamente para a ação por vezes transborda para os interesses privados e para o engenho que tutela as ações que não coincidem com a utilidade comum. Espinosa reflete com precisão sobre quais seriam os limiares nos quais se impõem o direito; a conclusão mais clara é que não se pode legislar sobre muitas coisas, assinaladamente, sobre as coisas subjetivas. As cláusulas do direito natural não se suportam em distinções nas quais há noções como "correto" ou "incorreto" como critérios heterônomos: apenas a exterioridade das ações podem ser reconhecidas como submetidas ao império do permitido e do proibido pelo direito. ${ }^{14}$ Assim, pois, a noção de "pecado" corresponde a uma noção que está em poder do Estado, e, dado conta de que o pensamento não está submetido a leis possíveis de sancionar, ele - o pensamento - tem tanto alcance quanto tem a potência de cada intelecto.

\section{***}

O direito natural é o que pode e deve governar as questões de consciência; os atos, por sua parte, são governados pelo direito positivo, pois os fatos que se apresentam como infratores no marco da vida social são objeto da justiça. Os limites do direito natural são ilimitados: abrange todas as liberdades que, por meio da razão ou da imaginação, se desdobrem na ordem da subjetividade. Em troca, os atributos do direito positivo são tangíveis, pois tipificam os atos como algo que está dentro ou fora da lei. O juiz que tutela as liberdades da consciência é, em cada caso, o próprio indivíduo que pensa ou imagina. Ao direito natural não corresponde fazer o discernimento entre o bom e o mau em matéria intelectual; um pensamento que expressa a potencia de pensar e outro que corresponde à potência da imaginação não estão em poder de nenhuma autoridade: essa distinção é uma tarefa para o método. 
Os direitos hermenêuticos que reivindica Espinosa para os indivíduos - que cada qual seja juiz do que crê - são exigidos em nome da razão. O marco espinosano de interpretação das Escrituras não aceita que as origens destas tenham uma fonte revelada e misteriosa; o fundamento hermenêutico de que provêm suas leituras se remontam ao exame livre e racional. Porém Espinosa não fica satisfeito em assumir esse direito como uma mera perspectiva de análise. Daí transita até o argumento pelo qual declara que isso não pode ser apenas uma concessão à razão. Não somente é necessário para o cumprimento dos fins do Estado deixar cada cidadão como dono de seu universo subjetivo. Quando chega a pôr essa tese de uma maneira mais radical, sustenta que as opiniões e as ideias não podem ser objeto de nenhum limite. Subtrair de todo tipo de autoridade o monopólio da interpretação das Escrituras é, antes de tudo, uma garantia para a preservação da paz da comunidade política. A liberdade é consumada na entronização dos direitos ao livre juízo, que nenhum tipo de poder eclesiástico ou civil pode confiscar. A tentativa de diferenciar conhecimento de profecia não é resolvida por Espinosa a partir de uma disjunção; ao liberar uma de outra, cada uma delas reconhecerá os confins nos quais teriam legitimidade em seu exercício. Entre a obediência que propicia a religião e a livre investigação não há senão uma falsa disjunção, pois Espinosa reconhece os foros de uma e de outra no marco da liberdade democrática.

\section{REFERÊNCIAS BIBLIOGRÁFICAS:}

1. BERLIN, I. Conceptos y categorías, México: FCE, , 1992.

2. ESPINOSA .Ética. Vérsion de Atilano Dominguez. Madrid: Ed. Trotta, 2000. Tratado Teológico Político. Vérsion de Atilano Dominguez. Madrid: Alianza editorial, 1986.

4 Tratado politico. Vérsion de Atilano Dominguez. Madrid: Alianza editorial, 1986.

5. ___ Correspondencia. Madri: Alianza Editorial, 1988.

6. GADAMER. Verdad y método, Salamanca: Ed. Sígueme, 1988.

7. GUEROULT, M. Spinoza, Ethique 1, (Dieu), Paris: Aubier Montaigne, 1968.

8. HAYON, M. L'exégese philosophique dans le judaisme medieval, Tubingen: Mohr, 1992.

9. MATHERON, A. Le Christ et le salut des ignorants chez Spinoza, Paris: Aubier Montaigne, 1971.

10. SILVER, D. Maimonidean criticism and the maimonidean controversy 1180-1240, Leiden: E. J. Brill, 1965.

11. STRAUSS, L. Die Religionskritik Spinozas als Grundlage seiner Bibelwissenchaft, Hildesheim - New York: Georg Olms Verlag, 1981.

12. ZAC, S. L'idée de vie dans La Philosophie de Spinoza, Paris: PUF, 1963.

13. __ Spinoza et l'interpretation de l'Ecriture, Paris: PUF.

\section{Hermeneutics and subjective pluralism: the foundation of freedom in Spinoza's} thought

Abstract: The main aim in this paper is to expose one of the greatest aspirations of Spinoza's philosophy: the liberation of the faculty to judge as hermeneutic perspective as well as in its political sense. Taking this concept as starting point, our aim is to reconstruct some of the interstices of the philosopher's program, who is always emphatic with regard to the freedom in ethical and political ambit, as well as to reconstitute the several senses that this concept has in his work. Is there a freedom that is sub specie aeternitatis conceived and another that is sub specie durationis? This question leads us to establish the relation that this philosopher has to the political world's things, which he always thinks in terms of passions and interests, excluding 
from it a sense of freedom in which it is conceived as virtuous. Without abandoning the aspirations of a superior sense of freedom, the author maintains that Spinoza proposes to examine the problem of freedom in a context in which there are more prejudices than adequate ideas, more fear than hope, more superstition than wisdom.

Keywords: freedom, biblical hermeneutic, faculty to judge

\section{NOTAS:}

1. Alguns autores, particularmente Silvain Zac (12, p. 207-242), foram influenciados pela tipologia da vida social formulada por Ferdinand Tonies e a antinomia básica entre sociedade e comunidade; com efeito, S. Zac considera que a teoria política espinosana se dirige a construir um espaço de convivência que se aproxima da "comunidade dos santos", quer dizer, a um modelo de tipo apostólico e comunitário que se opõe à sociedade entendida como um contrato; nossa proposta interpretativa pretende mostrar que o valor supremo do espinosismo não radica na felicidade senão na liberdade que garante à comunidade política assumir plenamente seus direitos subjetivos.

2. Espinosa utiliza, com efeito, um procedimento racional para construir a ideia de Deus. A racionalização da ideia de Deus nada teria em comum com uma concepção como a que oferecem as teologias que tomam como ponto de partida a revelação e sua suposição mais fundamental, a saber, que Deus é um ser do qual não se pode ter uma ideia clara e que sua essência permanece velada à alma humana. O ponto de partida de Espinosa não se sustenta no mistério senão na construção metódica de uma ideia que serve de ponto de partida a todo tipo de trama teórica. Não sabemos o que é Deus se não sabemos como são seus atributos; deste ponto partem as definições e proposições que compreendem os temas expostos desde a Definição 1 até a proposição 11 da Ética. A propósito dessa tendência racionalista se podem encontrar notas de altíssima precisão em um clássico dos estudos espinosanos, a obra de Martial Gueroult (7, particularmente as páginas 11-16).

3. Espinosa sustenta, com efeito, que em todo intelecto, sem importar a qualidade deste, se apresenta a ideia de Deus e não faz nenhuma distinção entre o homem que é capaz de concebê-la clara e distintamente daquele que apenas forma uma ideia imaginária e supersticiosa Dele. Assim é sustentado na proposição 15 da Ética: "Tudo o que é, é em Deus, e sem Deus nada poder ser nem ser concebido". A universalidade dessa proposição alcança, como é de esperar-se, o conhecimento imaginário. As consequências dessa afirmação também podem ser percebidas no exame que Espinosa faz acerca da superstição no TTP, no qual Deus se concebe a partir de "um culto externo", quer dizer, dos prejuízos e da credulidade. Cf. notadamente o prefácio, p.67.

4. Leo Strauss sustenta que a finalidade superior que persegue Espinosa, a liberdade de pensamento, tem de passar necessariamente pela crítica dos dogmas dos teólogos. Com efeito, pelos anos em que escreve o TTP, inicia uma polêmica correspondência com um "teólogo aficcionado" chamado Willem van Blijenberg. Espinosa pensa neste e em outros personagens semelhantes quando escreve sua perspectiva crítica das religiões. Pode-se dizer que a liberdade de pensamento é uma coroação da odisseia das liberdades. Por isso, a crítica aos prejuízos dos teólogos não é extrínseca à filosofia, e sim o prolegômeno necessário para esta: uma vez que os prejuízos dos teólogos tenham perdido seu poder sobre as consciências, fica livre o campo para a filosofia (Cf. Strauss 11, p.88). Porém se só existe liberdade ali onde há razão, põem-se abaixo todos os argumentos jusnaturalistas sobre a impossibilidade de governar à subjetividade. Esse ponto de vista de Strauss só explica a liberdade como uma realização do intelecto, mas não como uma condição indispensável para o governo de uma cidade que pode incluir, a partir da tolerância, os prejuízos dos ignorantes assim como os filósofos que se tenham liberado dos prejuízos. Tal é o sentido da carta XXX (a Oldenburg) na qual Espinosa assume esta posição: "Por isso, deixo que cada qual viva segundo seu bem parecer e que os que assim o desejem, que morram por seu bem, desde que a mim me seja lícito viver para a verdade" (Espinosa 5, p.231).

5. Gadamer formula sua exegese do conceito de prejuízo tomando Espinosa como um pensador que precede e influi na Ilustração. Com efeito, podemos considerar o jusnaturalismo como uma espécie de protoilustração que se propõe a relativizar no horizonte da vida social o papel da superstição religiosa, que se vincula de uma maneira direta com a fonte mais poderosa dos prejuízos. O jusnaturalismo de Espinosa tem a particularidade de despojar do conceito de autoridade política o poder de arbitrar o verdadeiro e o falso em matéria de fé. Uma das formas da liberdade consiste, efetivamente, em desprender-se dos prejuízos. Gadamer assume a tese de Leo Strauss, formulada em Die Religionskritik Spinozas, segundo a qual: 'O termo 'prejuízo' é a expressão mais adequada para a grande vontade da Ilustração, a vontade de um exame livre e sem coerções. Prejuízo é o correlato polêmico inequívoco desse termo tão excessivamente equívoco que é a liberdade" (citado em Gadamer 6, p.337). A leitura 
que propomos fazer sobre Espinosa se orienta em sentido diverso à que formulam tanto Leo Strauss como Gadamer em sua exposição sobre esta crítica na Ilustração: a liberdade tem sua expressão mais virtuosa na superação do prejuízo. No entanto, não se pode ignorar que Espinosa é também um filósofo que se propõe explicar a liberdade antes da conquista da razão. A liberdade não surge com a razão: é um direito natural. Por isso mesmo, entende todos os indivíduos como dotados pela natureza dessa condição original; a liberdade é uma conquista virtuosa da razão, contudo é uma condição da qual nasce dotado todo homem. A liberdade existe apesar do prejuízo e da superstição, não porque se as eliminou.

6. "Aqueles que não sabem separar a filosofia da teologia discutem se a Escritura deve ser escrava da razão ou, ao contrário, a razão da Escritura. Este último é defendido pelos céticos, que negam a certeza da razão; o primeiro, em troca, pelos dogmáticos". (Espinosa 3, p.320).

7. Maimônides representa o casamento entre Atenas e Jerusalém, Segundo uma afortunada expressão de Daniel Jeremy Silver (10, p.1). Esse matrimônio desaprovado por Espinosa, surgido da atmosfera tolerante e aberta do judaísmo arraigado na Espanha do séc. XIII, é uma das causas da tendência especulativa dentro das igrejas. Aqui a crítica vale para Maimônides, porém igualmente para qualquer doutor de qualquer igreja. Maimônides não precisa ser apresentado de uma maneira detalhada nas grandes tradições exegéticas do judaísmo, pois qualquer livro relativamente importante o registra. Em troca, Alfakhar requereria um maior credenciamento, contudo não o tem ou é difícil de rastrear. Maurice R. Hayon e sua L'exégese philosophique dans le judaisme medieval não o faz nem uma vez.

8. "Antes da vinda de Cristo, os profetas costumavam predicar a religião como a lei da pátria e em virtude da aliança feita no tempo de Moisés; em troca, depois da vinda de Cristo, os apóstolos predicaram todos como lei universal e em virtude apenas da paixão de Cristo.” (Espinosa 3, XII, ii, p. 295).

9. Alexandre Matheron insistiu sobre esse ponto em Le Christ et le salut des ignorants chez Spinoza: "Ora, Cristo ensina ex cathedra o dogma da salvação dos ignorantes" ( 9 , p.250). Posteriormente se pergunta "quais consequências se pode inferir daí? Parece que só uma, extremamente vaga: Cristo haveria ido demasiado longe no conhecimento de terceiro gênero" $(9$, p. 251$)$.

10. Um dos mestres do liberalismo, Isaiah Berlin, justifica o pluralismo a partir da pertinência da filosofia política. O totalitarismo se refugia na presunção a partir da qual se declara, como objeto da ação política, um fim soberano, absoluto, incontroverso. A pertinência da filosofia radica em que, até agora, a ciência não disse a última palavra sobre quais são esses fins últimos; portanto, corresponde a uma visão plural das coisas seguir explorando esses fins divergentes; a pretensão de que um regime é possuidor objetivo da justiça, ou de qualquer outro valor, conduz a ficções que servem para justificar o terror: “....a crença em tais ficções se atribui psicologicamente ao medo da liberdade - a ser abandonado por suas próprias forças; terror que conduz à aceitação acrítica de sistemas que pretendem possuir autoridade objetiva de espúrias cosmologias teológicas ou metafísicas que se ergueram como garantias da eterna validez de regras e princípios morais e intelectuais" (Berlin 1, p. 253). O precedente mais claro dessa primeira parte da formulação radica na obra de Espinosa; só que, em Espinosa, se professa a ideia de que a razão comporta um sentido absoluto do que seria o bem para uma comunidade política.

11. Em um mesmo teor argumentativo, Espinosa arremete contra os prejuízos gerados pelas ilusões da vontade nascida da imaginação: "Será suficiente que se tome por fundamento aquilo que todos devem reconhecer, a saber, que todos os homens nascem ignorantes das causas das coisas e que todos têm apetite de buscar sua utilidade e são conscientes disso. Pois disso se segue: 1) que todos os homens opinam que são livres, porque são conscientes de suas volições e de seu apetite, e nem por sonhos pensam nas causas pelas quais estão inclinados a apetecer e a querer, posto que as ignoram. Se segue: 2) que os homens fazem tudo por um fim, quer dizer, pela utilidade de que apetecem" (Espinosa 2, I, apêndice, p.68).

12. Evidentemente Espinosa toma como processos correlatos a liberdade e a paz. O TTP defende com maior vigor o valor da paz; porém, com igual veemência sustenta o TP (Espinosa 4, p. 119), que a paz é uma das razões pelas quais se forma parte de uma comunidade política: "Qualquer que seja a constituição de um Estado qualquer, se deduz facilmente a finalidade do estado político, que não é outra que a da paz e da segurança da vida. Aquele Estado é, portanto, o melhor, no qual os direitos comuns se mantêm ilesos." O irenismo_de Espinosa não se coloca como fundamento da paz pela liberdade e vice-versa: uma paz que não suponha a liberdade é tirania; uma liberdade que não suponha a paz é estado de natureza.

13. Espinosa não aspira somente construir uma "sociedade de sábios" que vivam isolados dos ignorantes: aspira a que as paixões dos ignorantes não determinem o rumo do Estado (Espinosa 3, prefácio, p.8). Inclusive eles têm o direito de existir sob a proteção do direito da república. Porém não menor é o direito dos homens racionais ao livre exame de todas as questões do pensamento. Não somente deve 
tolerar passivamente os ignorantes: o sábio deve aspirar a difundir o "uso público da razão". S. Zac pôs claramente essa questão: também o sábio, que se nutre da verdade, obrigado a viver entre os não sábios, deve defendê-la em nome da verdade a que aspira e a que, em princípio, todos podem aceder. Essa liberdade de pensar abre uma via para a vida verdadeiramente humana (Zac 13, p. 3).

14. É no âmbito do direito positivo que Espinosa reconhece como noção apropriada o "pecado". Não se trata de uma noção moral ou teológica, como podem ilustrar as seguintes palavras de Espinosa: "Pelo dito entendemos facilmente que no estado de natureza não há nada que seja bom ou mau pelo acordo de todos; pois todo aquele que está no estado natural olha tão só para sua utilidade e decide, segundo seu engenho e tendo em conta sua utilidade, o que é bom e o que é mau, e não está obrigado por lei alguma a obedecer a ninguém, fora ele mesmo; daí que no estado natural não seja concebível o pecado. Porém sim no estado civil, onde por comum acordo se decide o que é o bem e o que é o mal, e cada um está obrigado a obedecer ao Estado. O pecado não é outra coisa que a desobediência, a qual é castigada pelo direito do Estado.”

(Espinosa 2, IV, P38, esc. 2, p. 210).

\section{A CONCEPÇÃO DE NATUREZA HUMANA EM} BENEDICTUS DE SPINOZA*

\section{Emanuel Angelo da Rocha Fragoso**}

Resumo: Spinoza concebe a natureza humana em sua obra Ethica como constituída por modos de dois dos infinitos atributos de Deus, o pensamento e a extensão, ou a ideia e seu objeto, o corpo, respectivamente. A mente humana, enquanto essencialmente uma ideia, e o objeto desta ideia, o corpo, pressupõe uma relação não causal entre um modo finito do atributo pensamento e do atributo extensão. O corpo, enquanto certa relação composta ou complexa de movimento e de repouso se mantém através de todas as mudanças que afetam suas partes, está continuamente sujeito ao acaso dos encontros (occursus), ou ao impacto dos múltiplos e variados corpos a sua volta. A mente reflete estes encontros e através deles, ou das afecções corporais, conhece os corpos externos. É a ideia-afecção. É o conhecimento imaginativo, ou o conhecimento condicionado pela situação de nosso próprio corpo, por nosso temperamento, nossa experiência prévia e nossos preconceitos.

Palavras-chave: Spinoza. Ethica. Natureza humana. Mente. Corpo.

\section{Introdução}

Há milênios a alma é considerada o suporte místico de inúmeras seitas, religiões e assemelhados, e como tal, é tida como sendo em muito superior ao corpo, seja quanto à sua infinitude, em oposição à finitude do corpo, seja quanto às suas funções, de controle ou de comando sobre o

* Este texto é uma versão modificada e ampliada de nossa Palestra apresentada no Colóquio Natureza e Linguagem, realizado no período de 12 a 14 de setembro de 2006, na Universidade Federal do ceará - UFC. ** Universidade Estadual do Ceará - UECE 